\title{
Correction to: Timely initiation of breastfeeding in Zimbabwe: evidence from the demographic and health surveys 1994-2015
}

Sanni Yaya ${ }^{1,2^{*}}$, Ghose Bishwajit ${ }^{1}$, Gebretsadik Shibre ${ }^{3}$ and Amos Buh ${ }^{4 \dagger}$

\section{Correction to: Int Breastfeeding J http://dx.doi.org/10.1186/s13006-020-00255-2}

Following publication of the original article [1], the authors have flagged that the article contains the following errors:

1- All instances of the year '1994' should instead be '1999'

2- The article should refer to 'four rounds of Zimbabwe Demographic and Health Survey data' (not 'five rounds...')

3- In the Conclusions of the article, it should read ' $67 \%$ higher than the 50\% target' (not ' $70 \%$ higher...')

The authors apologize for any inconvenience caused.

\section{Author details}

${ }^{1}$ School of International Development and Global Studies, Faculty of Social Sciences, University of Ottawa, 120, University Private, Ottawa, ON K1N 6 N5, Canada. ${ }^{2}$ The George Institute for Global Health, The University of Oxford, Oxford, UK. ${ }^{3}$ School of Public Health, College of Health Sciences, Addis Ababa University, Addis Ababa, Ethiopia. ${ }^{4}$ Interdisciplinary School of Health Sciences, Faculty of Health Sciences, University of Ottawa, Ottawa, Canada.

Published online: 04 May 2020

\section{Reference}

1. Yaya, et al. Timely initiation of breastfeeding in Zimbabwe: evidence from the demographic and health surveys 1994-2015. Int Breastfeeding J. 2020; 15:10. https://doi.org/10.1186/s13006-020-00255-2.

The original article can be found online at https://doi.org/10.1186/s13006020-00255-2.

*Correspondence: hsanniya@uottawa.ca

†Sanni Yaya and Amos Buh contributed equally to this work.

'School of International Development and Global Studies, Faculty of Social Sciences, University of Ottawa, 120, University Private, Ottawa, ON K1N 6 N5, Canada

${ }^{2}$ The George Institute for Global Health, The University of Oxford, Oxford, UK Full list of author information is available at the end of the article

(c) The Author(s). 2020 Open Access This article is licensed under a Creative Commons Attribution 4.0 International License, which permits use, sharing, adaptation, distribution and reproduction in any medium or format, as long as you give appropriate credit to the original author(s) and the source, provide a link to the Creative Commons licence, and indicate if changes were made. The images or other third party material in this article are included in the article's Creative Commons licence, unless indicated otherwise in a credit line to the material. If material is not included in the article's Creative Commons licence and your intended use is not permitted by statutory regulation or exceeds the permitted use, you will need to obtain permission directly from the copyright holder. To view a copy of this licence, visit http://creativecommons.org/licenses/by/4.0/. The Creative Commons Public Domain Dedication waiver (http://creativecommons.org/publicdomain/zero/1.0/) applies to the data made available in this article, unless otherwise stated in a credit line to the data. 